\title{
Dinamika Struktur Komunitas Mikroalga Kodominan Waduk Sutami Malang Akibat Penambahan Variasi Konsentrasi Deterjen secara Ex-Situ
}

\author{
Titik Wijayanti \\ Program Studi Pendidikan Biologi FPIEK IKIP Budi Utomo Malang \\ Jalan Citandui 46 Malang
}

\begin{abstract}
The study aims to determine the response of microalgae community structure codominant and abiotic factors change Sutami Malang waters due to the addition of the detergent concentration variation in ex-situ. The experiment was conducted in September 2007 to March 2008. The addition of the detergent concentration consists of four levels, namely D0 (0 ppm), D1 (0.1 ppm), D2 (2 ppm) and D3 (4 ppm) of detergent to the water reservoir. Variable dynamics of microalgae abundance and abiotic factors waters observed simultaneously and periodically every five days for 40 days. The results showed that increasing the concentration of detergent changing dynamics of microalgae community structure codominant. Detergents suppress the growth Ceratium at a concentration $\geq 0.1$ ppm. Instead detergent Synedra population increases until day 30 and stimulate the growth of Microcystis. During the 40 days of observation, abiotic factors change due to the addition of detergent concentration, especially the increase in conductivity, Total Organic Matter, phosphate, nitrate and surfactant. In contrast to lower CO2-free detergents and Dissolved Oxygen. Changes in abiotic factors significantly affect the growth of microalgae codominant.
\end{abstract}

Keywords: dinamika struktur, komunitas mikroalga kodominan, Waduk Sutami

Waduk Sutami terletak $\pm 50 \mathrm{~km}$ di sebelah selatan Kota Malang di Desa Karangkates, Kecamatan Sumberpucung, Kabupaten Malang. Waduk Sutami memiliki fungsi utama yaitu sebagai Pembangkit Listrik Tenaga Air (PLTA). Selain fungsi utama tersebut, Waduk Sutami juga memiliki beberapa fungsi pendukung lainnya seperti sebagai pengendali banjir, pengembangan perikanan darat serta pariwisata [1]. Sebagaimana halnya waduk-waduk lainnya, maka Waduk Sutamijugamenciptakanekosistem perairan yang memiliki keanekaragaman cukup tinggi sehingga Waduk Sutami ini juga memiliki fungsi konservasi.

Adanya limbah deterjen yang tinggi di Waduk Sutami memberikan efek negatif bagi ekosistem perairan baik sifat fisika, kimia dan biologi air maupun jumlah dan jenis organisme yang ada diperairan tersebut. Jika terdapat limbah deterjen, maka akan menimbulkan busa berlebih akibat gerakan air, yang mengakibatkan terhalangnya oksigen untuk masuk ke badan air sehingga oksigen terlarut (DO) menurun, $\mathrm{CO}_{2}$ bebas meningkat, terjadi perubahan nilai $\mathrm{pH}$ (menjadi basa) dan peningkatan kandungan fosfat menjadi salah satu faktor penyebab suburnya fitoplankton (blooming alga) yang diikuti dengan kenaikan zooplankton.

Deterjen merupakan zat pencemar yang tidak terdapat di alam atau bersifat antropogenik. Pencemaran deterjen yang melebihi nilai ambang 0,5 ppm pada ekosistem perairan dapat menimbulkan busa dan bila tertiup angin dapat menyebarkanmikrobiapatogen[2],[3]. Pengaruh deterjen terhadap lingkungan antara lain adalah gangguan estetika karena adanya busa putih di permukaan perairan, penurunan kadar oksigen perairan, kematian beberapa hewan air, tidak normalnya perkembangan embrio hewan, perubahan sifat fisika dan kimia air serta terjadinya eutrofikasi. Terjadinya eutrofikasi atau suburnya perairan ini diakibatkan oleh bahan penunjang dan bahan aditif deterjen berupa fosfat dan sulfat. Kandungan fosfat yang tinggi dapat merangsang tumbuhnya gulma air. Peningkatan jumlah tanaman air akan menyebabkan meningkatnya penguraian dan penghambatan pertukaran udara dalam air sehingga kadar oksigen terlarut dalam perairan menjadi sangat rendah. Keadaan ini dapat 
146 | Titik Wijayanti, Dinamika Struktur Komunitas Mikroalga Kodominan ...

menyebabkan pengurangan jumlah spesies dan individu organisme dan atau peningkatan kelimpahan spesies tertentu yang bersifat toleran [4], [5].

Keanekaragaman yang terdapat di Waduk Sutami selama bulan Oktober sampai Desember 2004, secara keseluruhan ditemukan 38 spesies fitoplankton dan 20 jenis zooplankton yang bervariasi jumlah jenis dan jumlah individu tiap jenis untuk tiap waktu pantau yang berbeda. Ditemukannya Ceratium sp. dengan kelimpahan yang tinggi pada waktu pantau tertentu menunjukkan bahwa Waduk Sutami sudah tercemar oleh bahan organik, sedangkan kelimpahan yang tinggi dari jenis Synedra spp. menunjukkan bahwa perairan tersebut sudah memiliki kadar nitrat yang tinggi. Sementara itu, kelimpahan Microcystis $\geq 34.037$ individu/ $\mathrm{ml}$ menyebabkan water bloom yang dapat mengeluarkan senyawa toksik yang mampu menghambat jenis mikroalga lainnya [6].

Berdasarkan latar belakang di atas, maka perlu dilakukan penelitian untuk menentukan responstrukturkomunitasmikroalgakodominan dan perubahan faktor abiotik perairan Waduk Sutami Malang akibat kontaminasi deterjen secara ex situ.

\section{METODE}

Penelitian ini menggunakan metode eksperimental dengan rancangan acak lengkap. Pengambilan contoh air dan mikroalga kodominan dilakukan di Waduk Sutami Kabupaten Malang. Sampel yang telah diambil kemudian dipindahkan ke lokasi penelitian ex situ yaitu di Rumah Kaca Laboratorium Ekologi dan Diversitas Hewan Universitas Brawijaya Malang dan ditempatkan pada bak dengan volume 30 liter yang disusun secara acak.

Air waduk pada masing-masing bak diberi perlakuan deterjen dengan empat konsentrasi yaitu $\mathrm{D}_{0}(0 \mathrm{ppm}), \mathrm{D}_{1}(0,1 \mathrm{ppm}), \mathrm{D}_{2}(2 \mathrm{ppm})$ dan $\mathrm{D}_{3}$ (4 ppm). Setiap perlakuan diulang sebanyak dua kali ulangan. Kemudian dilakukan pengukuran faktor abiotik secara langsung di lokasi ex situ yang meliputi suhu, $\mathrm{pH}$, konduktivitas dan Dissolved Oxygen (DO). Disamping itu, juga dilakukan pengambilan contoh air untuk dilakukan pengamatan di laboratorium yang meliputi $\mathrm{CO}_{2}$ bebas, Total Organic Matter, fosfat, nitrat dan surfaktan serta pengamatan kelimpahan mikroalga kodominan. Pengukuran tersebut dilakukan di Laboratorium Ekologi dan Biodiversitas Hewan, sedangkan pengukuran surfaktan dengan Methylen Blue Active Substance Methods dilakukan di Laboratorium Mikrobiologi Fakultas MIPA Universitas Brawijaya Malang. Pengambilan contoh dilakukan secara simultan dan periodik setiap lima hari sekali selama 40 hari.

Data hasil penelitian yang meliputi kelimpahan mikroalga kodominan tiap perlakuan selama pengamatan ditampilkan secara deskriptif. Penghitungan indeks kesamaan komunitas mikroalga kodominan menggunakan Microsoft Office Excell 2003. Sedangkan analisis Multiple Regression digunakanuntukmengetahuihubungan antara kelimpahan masing-masing mikroalga kodominan dengan faktor abiotik pada tingkat signifikansi 5\% menggunakan aplikasi program Minitab versi 13,3.

\section{HASIL DAN PEMBAHASAN}

Hasil pengamatan menunjukkan bahwa peningkatankonsentrasideterjenmengakibatkan terjadinya dinamika struktur komunitas. Indeks kesamaan komunitas mikroalga kodominan antar perlakuan deterjen berdasarkan variabel kelimpahan (Tabel 1), menjelaskan adanya perbedaan komunitas pada konsentrasi $\mathrm{D}_{0}-\mathrm{D}_{3}$ dan konsentrasi $\mathrm{D}_{1}-\mathrm{D}_{2}$ selama waktu pengamatan. Konsentrasi deterjen yang berbeda menyebabkan perbedaan respon pada struktur komunitas mikroalga. Sementara itu, selama waktu pengamatan komunitas pada kadar $\mathrm{D}_{2}$ $\mathrm{D}_{3}$ cenderung menuju pada kesamaan komunitas dengan indeks kesamaan sebesar $81-91 \%$. 
Tabel 1. Indeks Kesamaan Komunitas Mikroalga Kodominan antar Perlakuan Berdasarkan Variabel Kelimpahan

\begin{tabular}{cccccccccc}
\hline \multirow{2}{*}{$\begin{array}{c}\text { Komunitas } \\
\text { yang di } \\
\text { bandingkan }\end{array}$} & \multicolumn{1}{c}{ Indeks Kesamaan (IK) Komunitas (\%) per-Waktu Pengamatan (Hari ke-) } \\
\cline { 2 - 11 } & $\mathbf{0}$ & $\mathbf{5}$ & $\mathbf{1 0}$ & $\mathbf{1 5}$ & $\mathbf{2 0}$ & $\mathbf{2 5}$ & $\mathbf{3 0}$ & $\mathbf{3 5}$ & $\mathbf{4 0}$ \\
\hline D0-D1 & 70 & $82^{*}$ & 55 & 37 & $\underline{\mathbf{1 3}}$ & $82^{*}$ & 43 & 45 & 42 \\
D0-D2 & 54 & $89^{*}$ & 68 & 50 & $\underline{\underline{18}}$ & 30 & $\underline{7}$ & 33 & 62 \\
D0-D3 & 75 & 61 & 76 & 31 & $\underline{\underline{16}}$ & 38 & $\underline{4}$ & 40 & 61 \\
D1-D2 & 67 & 78 & 47 & 76 & $\mathbf{7 2}$ & 48 & $\underline{19}$ & 27 & 59 \\
D1-D3 & $81^{*}$ & 50 & 53 & 79 & $\underline{9}$ & 43 & $\underline{10}$ & 36 & 50 \\
D2-D3 & 74 & 68 & $91^{*}$ & 71 & $\underline{15}$ & 63 & 66 & $82^{*}$ & $81^{*}$ \\
\hline
\end{tabular}

Keterangan: *menunjukkan kedua komunitas sama (Indeks Kesamaan Komunitas $\geq 80 \%$

Perubahanstrukturkomunitasmenunjukkan perbedaan selama 40 hari pengamatan. Pada pengamatan hari ke-20 dan ke-30 menunjukkan indeks kesamaan komunitas yang relatif kecil (menurun). Hal ini dimungkinkan karena berkaitan erat dengan siklus hidup mikroalga. Siklus hidup mikroalga terutama Pyrrophyta, Cyanophyceae dan Bacillariophyceae dipengaruhi oleh intensitas cahaya, senyawa organik, silika dan salinitas. Bacillariophyceae (Diatom) air tawar memiliki siklus yang lebih pendek dari Diatom air laut, karena kandungan mineral pada ekosistem air laut lebih beragam [7].

Perlakuan deterjen menekan pertumbuhan Ceratium pada konsentrasi $\geq 0,1 \mathrm{ppm}$. Sebaliknya perlakuan deterjen dapat meningkatkan populasi Synedra hingga hari ke-30 dan merangsang pertumbuhan Microcystis spp (Gambar 1). Selama waktu pengamatan, Ceratium sp menunjukkan sensitivitas tinggi terhadap deterjen. Hal berbeda terjadi pada Synedra spp dimana pada perlakuan $\mathrm{D}_{0} \quad\left(\begin{array}{lll}0 & \mathrm{ppm}\end{array}\right)$ terjadi dominansi Synedra spp. Semakin tinggi konsentrasi deterjen yang diberikan semakin menurunkan populasi Synedra.

(a) Ceratium sp

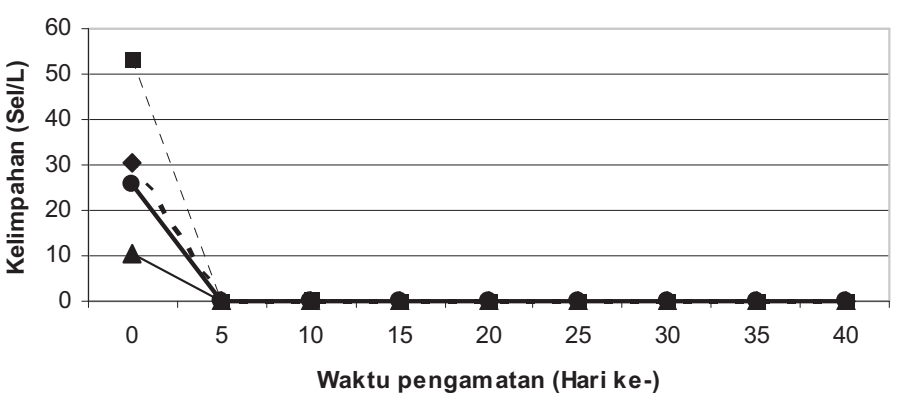

(b) Synedra spp

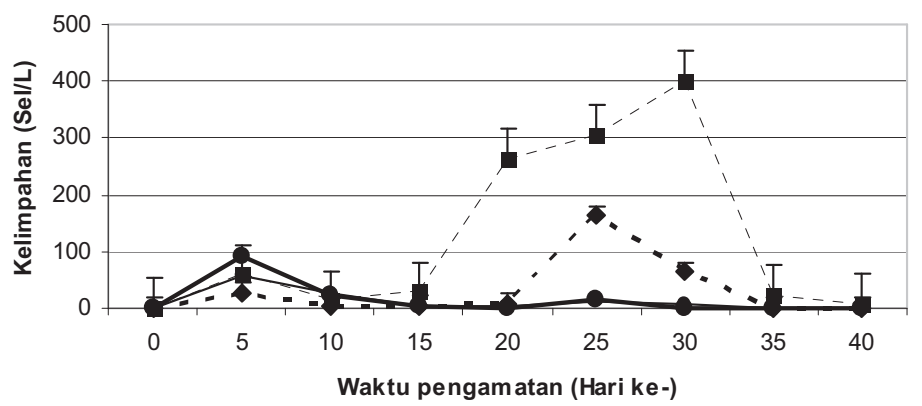


148 | Titik Wijayanti, Dinamika Struktur Komunitas Mikroalga Kodominan ...

(c) Microcystis spp

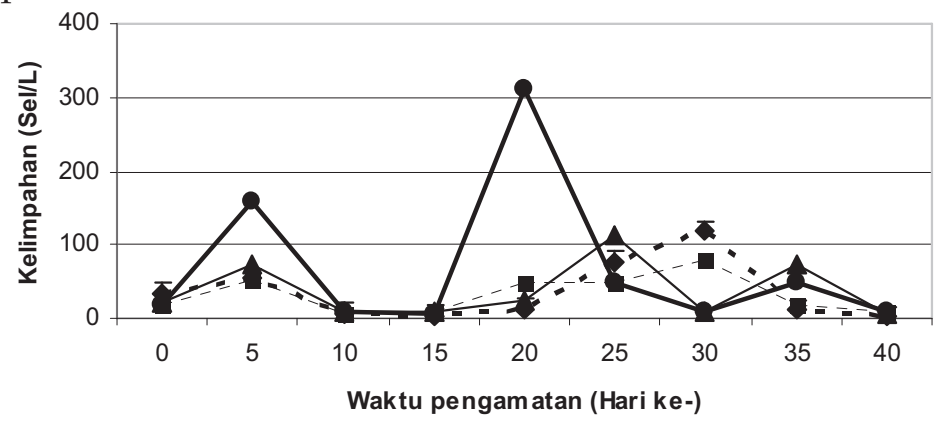

$--\mathbf{a - 0} 0$ ppm $=$ - $-0,1 \mathrm{ppm} \longrightarrow 2 \mathrm{ppm} \longrightarrow 4 \mathrm{ppm}$

Gambar 1. Dinamika Kelimpahan Mikroalga Kodominan sebagai Fungsi Waktu Tiap Kadar Deterjen (a) Ceratium sp, (b) Synedra spp, dan (c) Microcystis spp.

Respon Synedra berbanding terbalik dengan Microcystis, pemberian konsentrasi deterjen sebesar 4 ppm masih bisa tumbuh dengan baik. Diduga ini disebabkan adanya bahan penunjang pada deterjen yang diberikan yaitu berupa fosfat. Fosfat merupakan sumber nutrisi bagi Microcystis spp untuk dapat tetap tumbuh [8].

Terjadinya perubahan struktur komunitas juga diamati berkaitan dengan adanya perubahan faktor abiotik media akibat penambahan deterjen. Hasil pengamatan menunjukkan bahwa terjadi perubahan faktor abiotik media akibat penambahan konsentrasi deterjen terutama peningkatan bahanorganik(TOMdansurfaktan), fosfat dan nitrat (Gambar 2). Pengaruh utama bahan organik di perairan adalah mengurangi kadar oksigen terlarut (deoxygenation) sebagai akibat dari proses dekomposisi secara aerobik, yang selanjutnya mengakibatkan terjadinya perubahan struktur komunitas [9], [10].

a) TOM (Total Organic Matter)

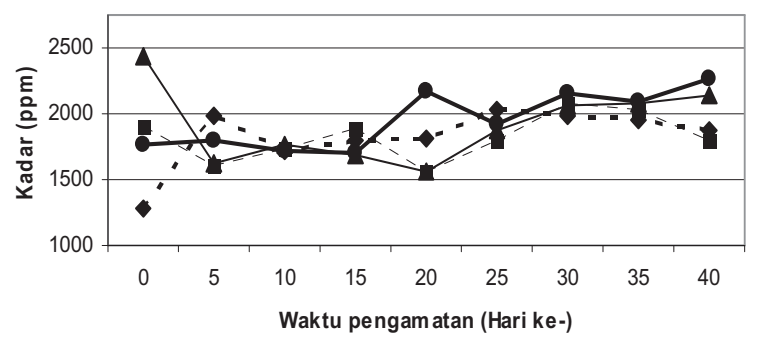

b) Fosfat

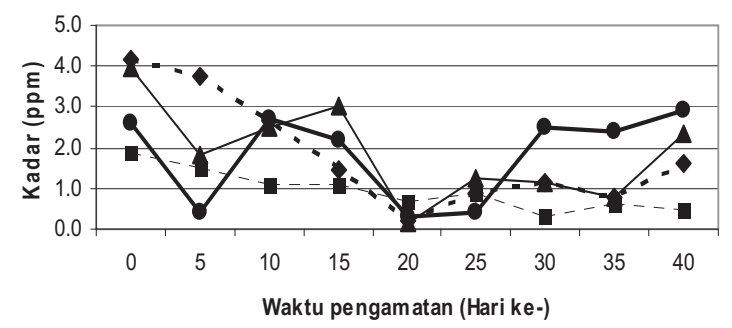

c) Nitrat

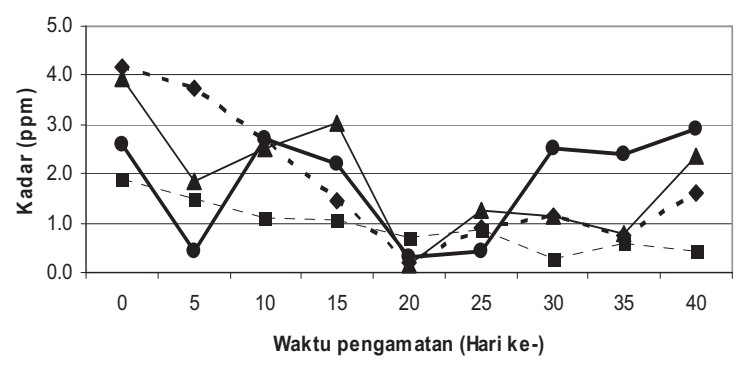

d) Surfaktan

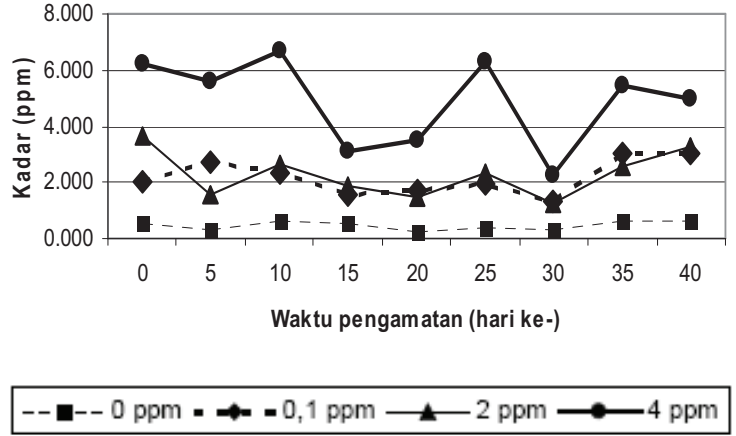

Gambar 2. Kualitas Media sebagai Fungsi Waktu untuk Tiap Kadar Deterjen

(a) TOM, (b) Fosfat, (c) Nitrat dan (d) Surfaktan. 
Peningkatan konsentrasi deterjen cenderung menyebabkan Dissolved Oxygen (DO) berfluktuasi dan menurunkan $\mathrm{CO}_{2}$ bebas (Gambar 3). Nilai DO mempunyai variasi yang kecil selama penelitian. Kadar DO yang relatif tetap ini diakibatkan karena selama penelitian diberi tambahan aerasi. Sedangkan kadar $\mathrm{CO}_{2}$ bebas terlarut semakin mengalami penurunan selama penelitian. Kadar $\mathrm{CO}_{2}$ bebas terlarut di perairan dapat berkurang karena dimanfaatkan oleh mikroalga untuk proses fotosintesis [6]. Sementara itu, suhu dan $\mathrm{pH}$ kurang terpengaruh oleh peningkatan konsentrasi deterjen. Suhu perairan berfluktuasi tergantung pada suhu lingkungan. Penambahan deterjen menyebabkan $\mathrm{pH}$ cenderung basa [5].

a) DO (Dissolved Oxygen)

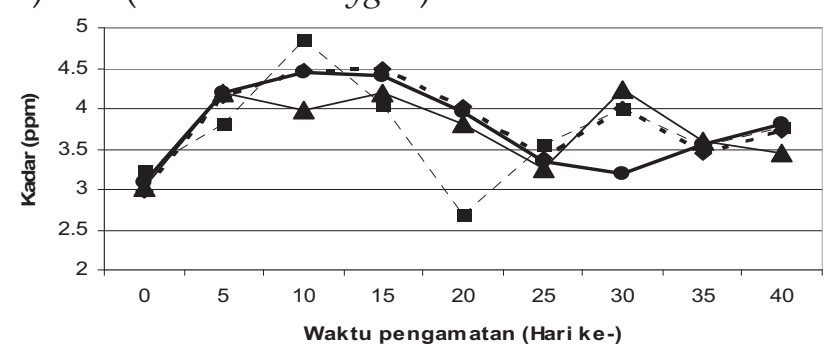

b) $\mathrm{CO}_{2}$ bebas

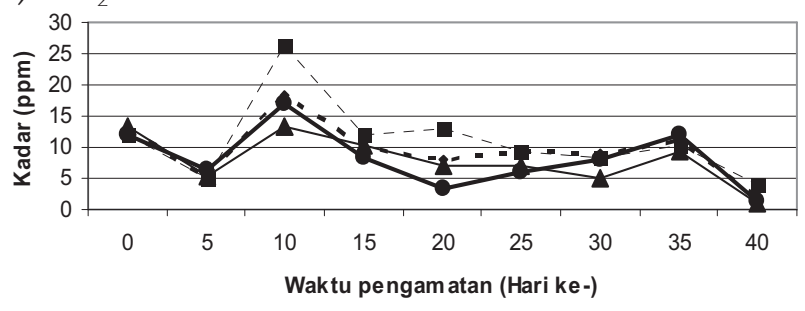

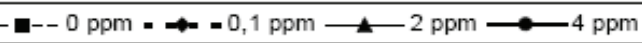

Gambar 3. Penurunan DO dan $\mathrm{CO}_{2}$ pada Tiap Kadar Deterjen (a) Dissolved Oxygen, (b) $\mathrm{CO}_{2}$ bebas.
Perubahan kelimpahan mikroalga kodominan akibat penambahan variasi deterjen, atau secara tidak langsung oleh perubahan faktor abiotik media air waduk diklarifikasi melalui hasil analisis Multiple Regression (Tabel 2). Faktor abiotik air waduk memberikan pengaruh bervariasi terhadap struktur komunitas mikroalga. Hal ini tergantung pada waktu pengamatan. Pada pengamatan hari ke-17, surfaktan nyata menghambat kelimpahan Ceratium bersama $\mathrm{CO}_{2}$ bebas sebesar $77,8 \%$. Hasil ini berbeda dengan penelitian sebelumnya yang menyatakan bahwa keberadaan Ceratium berkorelasi positif dengan kandungan karbon organik di perairan. Penggunaan karbon organik dapat meningkatkan laju metabolisme dan akibatnya menurunkan nilai DO [8]. Karbon organik berupa deterjen secara ex situ ternyata memberikan dampak berbeda dengan bahan organik lainnya yang menjadi pencemar Waduk Sutami. Sementara itu, pertumbuhan awal Microcystis justru dipacu oleh surfaktan dan bahan organik (TOM). Surfaktan merupakan bahan dasar deterjen. Hasil ini berbeda dengan penelitian sebelumnya dimana pertumbuhan Microcystis sangat dipengaruhi oleh kadar nitrat [8]. Tetapi pada pengamatan hari ke-40 hal serupa terjadi, dimana populasi Microcystis dipengaruhi oleh tingginya deterjen, suhu dan nitrat.

Tabel 2. Model Regresi Pertumbuhan Mikroalga Kodominan terhadap Faktor Abiotik Perairan

\begin{tabular}{|c|c|c|c|}
\hline $\begin{array}{c}\text { Hari } \\
\text { ke- }\end{array}$ & Genus & Model Regresi & $\begin{array}{c}\text { R-Sq } \\
(\%)\end{array}$ \\
\hline \multirow{2}{*}{17} & Ceratium & $\mathrm{y}=3,46-0,0131 \mathrm{CO}_{2}-0,112$ surfaktan* & 77,8 \\
\hline & Microcystis & $y=2,04-0,0604$ deterjen $+0,000998$ TOM $+0,0708$ surfaktan* & 86,0 \\
\hline 25 & Synedra & $y=9,51-0,0892$ deterjen ${ }^{* *}-0,216$ suhu $+0,0694$ surfaktan $* *$ & 92,6 \\
\hline 40 & Microcystis & $y=-8,08+0,158$ deterjen ${ }^{*}+0,567$ suhu $^{*}+0,0620$ nitrat $-2,47$ fosfat $-0,804 \mathrm{pH}^{*}$ & 99,9 \\
\hline
\end{tabular}

Keterangan:

* berpengaruh nyata pada tingkat signifikansi 5\%

** berpengaruh sangat nyata pada tingkat signifikansi $1 \%$ 
150 | Titik Wijayanti, Dinamika Struktur Komunitas Mikroalga Kodominan ...

Kelimpahan Synedra pada hari ke-25 nyata dihambat oleh penambahan deterjen dan peningkatan suhu, namun pertumbuhannya didorong penambahan kadar surfaktan. Hasil ini berbeda dengan penelitian sebelumnya bahwa populasi Synedra menurun bahkan sudah mati pada hari ke-25 akibat penambahan fosfat dan nitrat [8]. Selanjutnya populasi Synedra menurun setelah 30 hari pengamatan. Synedra termasuk Diatom yang menjadi bioindikator perairan dengan nitrat tinggi [8]. Kelimpahan Synedra ini dimungkinkan akibat kadar nitrat yang ditunjang dengan fosfat yang rendah dari deterjen yang ditambahkan. Sedangkan nilai $\mathrm{pH}$ dengan kisaran 5-9 mempunyai pengaruh langsung yang kecil terhadap organisme perairan [11].

Berbeda dengan respon Microcystis pada hari ke-17, maka pada hari ke-40 kadar deterjen, suhu dan kadar nitrat merangsang pertumbuhan populasinya. Sedangkan $\mathrm{pH}$ dan fosfat memberikan efek negatif. Hal tersebut disebabkan karena Microcystis sebagai bioindikator perairan yang bersifat eutrofik dengan kadar nitrat tinggi, memanfaatkan nitrat sebagai sumber energi dalam menghasilkan selsel baru dan koloni [11]. Kadar nitrat yang tinggi juga dapatmenstimulasi pertumbuhanganggang yang tak terbatas (jika beberapa syarat lain seperti kadar fosfat terpenuhi). Cyanophyceae juga dapat dominan pada perairan dengan $\mathrm{pH}$ di atas 7,0 [12].

\section{KESIMPULAN DAN SARAN}

Deterjen menekan pertumbuhan Ceratium pada konsentrasi $\geq 0,1$ ppm dan sebaliknya deterjen meningkatkan populasi Synedra hingga hari ke-30 serta merangsang pertumbuhan Microcystisspp.Selama40haripengamatanterjadi perubahan faktor abiotik akibat penambahan konsentrasi deterjen terutama peningkatan bahan organik (TOM dan surfaktan), fosfat dan nitrat. Sebaliknya deterjen menurunkan $\mathrm{CO}_{2}$ bebas dan DO. Perubahan faktor abiotik nyata mempengaruhi pertumbuhan mikroalga kodominan.

\section{DAFTAR RUJUKAN}

[1] Perum Jasa Tirta. Bendungan Sutami. http://www.jasatirta1.go.id/3WilKerja/ Bendungan/301Sutami. htm.Diakses pada 18 -10-2007.

[2] Jimenes, L., A. Breen, N. Thomas, T.W. Federly and G.S. Sayler. 1991. Mineralization of Linear Alkylbenzene Sulfonate (LAS) by four member aerobic bacteries consortium. App. Environment. Microbiol. 57 (5): 1566-1569.

[3] Van Ginkel, C.G. 1996. Complete degradation of xenobiotik surfactant by consortia of aerobic microorganism. Biodegradation. 7 : 151-164.

[4] Retnaningdyah, C., Prayitno dan S. Samino. 2001. Usaha standarisasi penggunaan invertebrata bentos sebagai bioindikator tingkat pencemaran deterjen di ekosistem perairan sungai. Laporan Riset Unggulan Terpadu VI. Kantor Menteri Negara Riset dan Teknologi. Dewan Riset Nasional. Jakarta.

[5] Ekowati, G., Nunung, Endang dan Khunur. 1992. Studi respirasi tanah sawah dan tegalan yang terkena deterjen serta usaha isolasi mikrobia tanah pengurai deterjen. Biosain: Jurnal Ilmu-ilmu Hayati. Vol.1 (4). Program Pascasarjana Universitas Brawijaya. Malang.

[6]Samino,S. danC. Retnaningdyah. 2004. Monitoring Dinamika Komunitas Fitoplankton dan Zooplankton di Waduk Sutami Malang Periode bulan Oktober sampai Desember 2004. Laporan Akhir Penelitian Kerjasama Perum Jasa Tirta I - Jurusan Biologi FMIPA Universitas Brawijaya. Sertifikat No. ID03/0127. Malang.

[7] Bold,H.Cand Wynne, M.J.1985. Introduction to The Algae: Structure and Reproduction (second edition). Prentice-hall, INC. Englewood Clift, N. J. 07632.

[8] Retnanigdyah, C. 2002. Potensi Mikroalga Sebagai Bioindikator Tingkat Pencemaran Bahan Organik di Perairan Waduk. Program Studi Biologi. Universitas Brawijaya. Malang.

[9] Pittwell, L.R. 1976. Biological Monitoring of Rivers in the Community. Dalam: Amavis, R. \& J. Smeets (ed.). Principles and Methods for Determining Ecological Criteria on Hydrobiocenoses. Pergamon Press. New York: 225-261. 
[10] Hawkes, H.A. 1976. Determinant in Freshwater Ecosystem and Man Modifiable Factor Inducing change in Hydrobiocenoses. Dalam: Amavis, R \& J. Smeeet (ed.) Principle and Methods for Determining Ecological criteria on Hydrobiocenoses. Pergamon Press, New York: 45-73.

[11] Ramires, J.J and C.E.M Bicudo. 2005. Diurnal and Spatial (Vertical) Dynamics of Nutriens $(\mathrm{N}, \mathrm{P}, \mathrm{Si})$ in Four Sampling Days (Summer,
Fall, Winter and Spring) in A Tropical Shallow Reversoir and Their Relationships with The Phytoplankton Community. Braz. J. Biol. 65(1): 141-157.

[12] Palmer, M.A and D.B Roy. 2001. An Estimate of The Extent of Dystrophic, Oligotrophic, Mesotrophic and Eutrophic standing fress water in great britania.http://www.jncc.gov.uk/ pdf/jncc 317text.pdf. tanggal akses 26 April 2002. 